\title{
Imaging-based assessment of rectus abdominis muscle thickness in an adult population: evaluating possible anthropometric relationships
}

\section{Ocena obrazowa grubości mięśnia prostego brzucha wśród dorosłych: określenie potencjalnych zależności antropometrycznych}

\author{
Ogugua Augustine Egwu12, Ukoha Ukoha Ukoha², Lasbrey A. Asomugha², Sylvester Okorie ${ }^{3}$ \\ ${ }^{1}$ Federal University, Ndufu-Alike Ikwo, Abakaliki, Nigeria \\ 2Department of Anatomy, NnamdiAzikiwe University, Nnewi Campus, Anambra State, Nigeria \\ ${ }^{3}$ Department of Anatomy, Ebonyi State University, Abakaliki, Nigeria
}

Key words: muscle, rectus abdominis, Nigeria, anthropometry.

Słowa kluczowe: mięsień, mięsień prosty brzucha, Nigeria, antropometria.

\begin{abstract}
Introduction: Very little attention has been paid to muscle architecture in the Sub-Saharan African environment, and the rectus abdominis muscle, being a stabilising agent in the trunk, should not be left out. Considering the incidence of trunk musculoskeletal discomfort, it is necessary to assess the rectus abdominis muscle.

Aim of the research: To assess the thickness of the rectus abdominis muscle in an apparently healthy adult population using ultrasound and to evaluate its possible relationship with important anthropometric variables.

Material and methods: A total of 120 healthy subjects made up of 60 males and 60 females, who gave their written consent, were recruited for this study. B-mode ultrasound was used to assess the rectus abdominis muscle. Anthropometric variables were also assessed.

Results: The results show that the rectus abdominis thickness (RAT) was $14.68 \pm 2.92 \mathrm{~mm}$ and $14.37 \pm 2.74 \mathrm{~mm}$ for the right (RRAT) and left (LRAT) sides, respectively. The males had significantly thicker muscles than the females $(p=0.004)$ and the RAT correlated positively with age, weight, height, body mass index, body surface area, waist circumference, and conicity index.

Conclusions: These results show robust myoanthropometric relationships that will assist surgeons in reconstructive procedures involving the muscle. They will also serve as a guidepost in the biomechanical assessment of the muscle in lifting sports for an African population, in the study of muscle flaps, and in the general evaluation of trunk mass.
\end{abstract}

\section{Streszczenie}

Wprowadzenie: W Afryce Subsaharyjskiej bardzo małą uwagę zwraca się na architekturę mięśni, a mięśnia prostego brzucha, który jest czynnikiem stabilizującym tułów, nie powinno się pomijać. W przypadku występowania bólów kostno-mięśniowych konieczna jest ocena mięśnia prostego brzucha.

Cel pracy: Ocena grubości mięśnia prostego brzucha w pozornie zdrowej populacji osób dorosłych za pomocą badania ultrasonograficznego oraz jej potencjalnego związku z ważnymi danymi antropometrycznymi.

Materiał i metody: Badaniem objęto łącznie 120 zdrowych mężczyzn (60) i kobiet (60), od których uzyskano pisemną zgodę. Ocenę mięśnia prostego brzucha przeprowadzono za pomocą badania ultrasonograficznego B-mode. Zebrano również dane antropometryczne.

Wyniki: Grubość mięśnia prostego brzucha (RAT) wyniosła 14,68 $\pm 2,92 \mathrm{~mm}$ i 14,37 $\pm 2,74 \mathrm{~mm}$ odpowiednio dla strony prawej (RRAT) i lewej (LRAT). Mężczyźni mieli istotnie grubsze mięśnie niż kobiety ( $p=0,004)$, a wartość RAT wykazywała pozytywną korelację z wiekiem, masą ciała, wzrostem, indeksem masy ciała, powierzchnią ciała, obwodem w talii i wskaźnikiem stożkowatości.

Wnioski: Wyniki wskazują na silne powiązania antropometryczne, które są pomocne dla chirurgów w przypadku zabiegów rekonstrukcji mięśni. Służą one również jako wskazówka w ocenie biomechanicznej mięśni w podnoszeniu ciężarów w populacji afrykańskiej, w badaniu płatów mięśniowych oraz w ogólnej ocenie masy tułowia. 


\section{Introduction}

Skeletal muscle architecture is the primary determinant of muscle function [1,2]. The knowledge of muscle architecture is of great practical importance in understanding the relationship between muscle structure, force, and extension ability [3]. Muscle architecture has been mainly characterised by fascicle length, pennation angle, and the thickness of the muscle [4-6].

Muscle thickness can be described as the cross-sectional diameter of the belly that extends from aponeurosis to aponeurosis. Its characterisation as part of the muscle architecture cannot be overemphasised, because of its role in the comparative assessment of gross morphology of muscles [7]. Muscle thickness is very important clinically in the assessment of atrophy and hypertrophy in neuromuscular diseases [8], in the estimation of general muscle volume [9], in the quantification of amyotrophic lateral sclerosis [10], and in the categorisation of the intensity of relationship with activity levels in cerebral palsy [11]. In the trunk, muscle thickness is used in the monitoring of trunk strengthening exercises necessary for therapeutic alleviation of low back pain [12-15] and other musculoskeletal disorders of the trunk.

The rectus abdominis (RA), as a flap-like muscle, is an important postural muscle that plays a role in movement and in stabilisation of the trunk. It helps the lower ribs, especially during expiration. It compresses the abdomen, supports the viscera (intestine), and is very important in weight lifting and other sports. The muscle, as a myocutaneous flap, has been used in numerous surgical reconstructions: in the reconstruction of scrotum [16]; reconstruction of the breast [17, 18]; closure of sternal defects [19]; in head and neck reconstructive surgery [20]; in the treatment of enterocutaneous fistula [21]; in the correction of pharyngoesophageal defects [22]; in soft tissue reconstruction of the hand [23]; in treatment of complex urethrovaginal fistulae $[24,25]$; in the reconstruction of full-thickness thoracic wall defects [26], and in the reconstruction of ankle and foot defects [27]. It is therefore obvious that detailed assessment of the thickness of the rectus abdominis muscleis very important, given its background in these myocutaneous reconstructive procedures.

Previous studies have tried to assess the thickness of the rectus abdominis muscle (RAMT) in different populations. Ikezoe et al. [28] reported that RAMT varies with the age and inactivity of anindividual. This report on the effect of age was also documented earlier by other findings [29-32]. In a different assessment, Balius et al. [33] reported that sportsmen had thicker muscles than non-sportsmen, emphasising the effect of the degree of activity/inactivity on muscle thickness. Also, other factors like posture, nutrition, sex, and pregnancy have been reported to affect the thickness of the rectus abdominis muscle [31, 32, 34, 35].
Anthropometric relationships of some abdominal muscles have been assessed by some studies. Rostami et al. [36] studied the relationship between the lateral abdominal muscles (the transversus abdominis, internal oblique, and external oblique muscles) and body mass index (BMI), abdominal skin fold thickness, and waist circumference and opined that these relationships were important in the assessment of fatness. Other studies, even though they were based on muscles of the extremity, reported a relationship between muscle thickness and some anthropometric variables and established that these myoanthropometric relationships were important in sex categorisation, anthropological categorisation, and lean body mass [7, 37].

Despite these reports, no study has comprehensively established any sort of myoanthropometric relationship using the rectus abdominis in our Sub-Saharan African environment, and since the muscle flap forms a reliable material in numerous reconstructive surgeries, it is absolutely necessary to assess the RAMT in an apparently healthy adult population with a view to creating and documenting information that will serve as a normogram for the African population, as well as a robust platform for comparison in clinical settings and a guidepost to studies on the biomechanical inclinations of the muscle. The RAMT assessment will be done using ultrasound (US). Most assessments of muscles are done with the use of ultrasound because real-time sonography enables in vivo muscle scanning and offers an assurance for a realistic determination of changes in muscle architecture $[6,38]$.

\section{Material and methods}

\section{Study design}

This study made use of B-mode ultrasound in measuring the rectus abdominis muscle thickness and was carried out within the Abakaliki metropolis, Ebonyi State, Southeast Nigeria.

\section{Study centre}

The Lifescan Ultrasound Centre located at Felix Memorial hospital, No. 6 Hilltop Road, Abakaliki, Ebonyi state, Southeast Nigeria was used. Patients from within the Abakaliki metropolis, Ogoja Metropolis, and beyond are received in this ultrasound and imaging centre. It is headed by a highly experienced radiographer.

\section{Participants}

A total of 120 healthy subjects made up of 60 males and 60 females, who gave their written consent, were recruited for this study after are search information sheet regarding the aims of the study, imaging procedure, rights of the subjects, and safety of ultrasound was given to each of them. They were selected from 

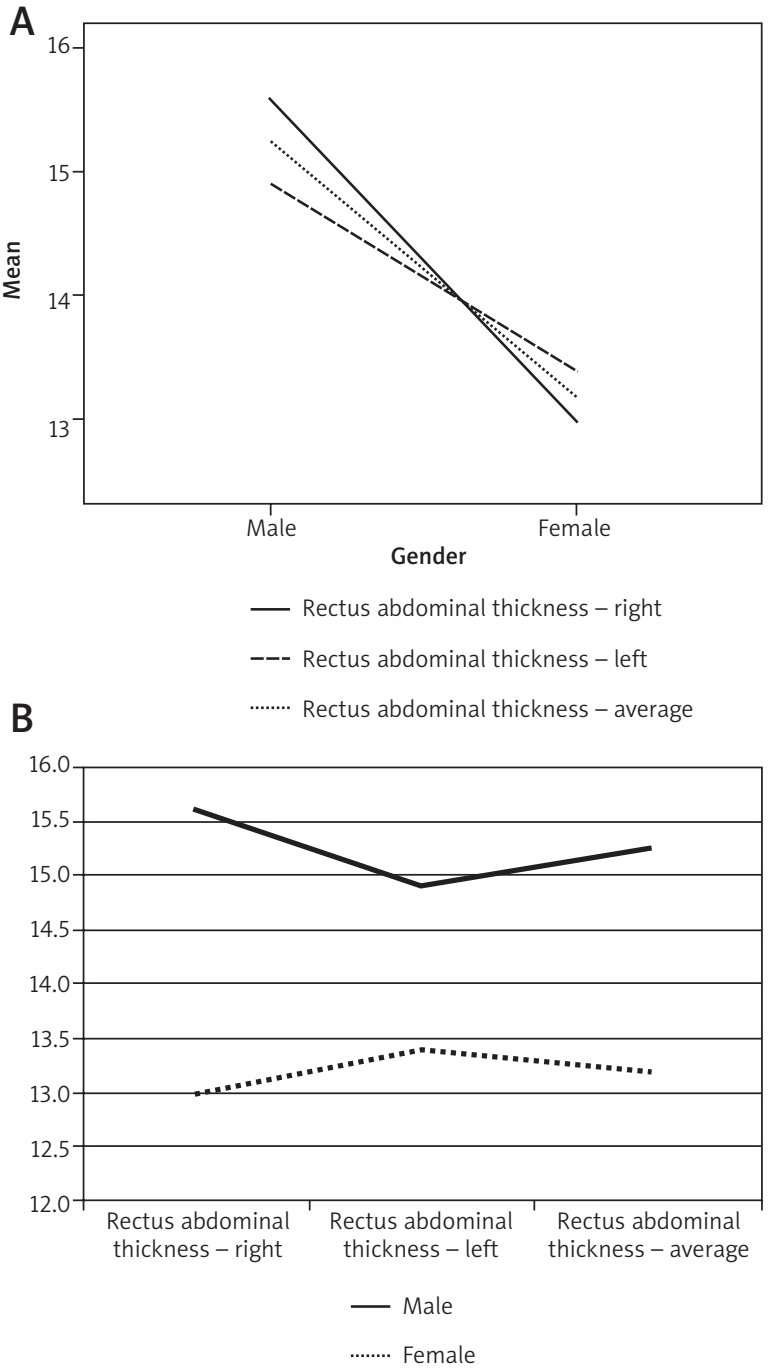

Figure 1. Line graph comparing RAT in RRAT, LRAT, and ARAT among young adults

a pool of students at Ebonyi State University (EBSU), who hail from Ebonyi State, Southeast Nigeria (Ebonyians) and were between the ages of 19 and 30 years.

\section{Criteria for selection of subjects}

The age range of the participants was from 19 to 30 years. The subjects were all students of Ebonyi State University (EBSU), who are Ebonyians without any history of low back pain in the preceeding three months, no history of performing core stability exercises in the past three months [36], including all forms of rigorous sports, and no potential metabolic diseases. This is to avoid any possible effect of these ailments on the musculoskeletal system. Also, none of the subjects had ever been pregnant or was pregnant at the time of the study, because pregnancy seems to affect the thickness of the rectus abdominis muscle [35].
Prior to the conduction of the main study, a pilot study was undertaken involving 6 subjects (12 RAM) to identify any potential errors in the planned study layout.

\section{Instrumentation}

An ultrasound system with a 7.5-MHZ linear transducer (Siemens sonoline SL-1, 1998 model) was used to measure the RAMT.

\section{Scanning protocol}

The subjects comprised 120 subjects, 60 males and 60 females. Each subject lay in a supine position while the thickness of the RA was measured at $3 \mathrm{~cm}$ lateral to the umbilicus (Figure 1). A 7.5-MHz ultrasound transducer was used to assess the RAMT on both sides. The RAMT was measured accurately using on-screen callipers, taking the distance between the inside edges of the fascia.

To avoid inter-observer variability, the same investigator took all the measurements. During the examination, care was taken to maintain the same standardised position of the subjects and the exact location of the transducer, which was held perpendicular to the skin surface using the minimum pressure required to achieve a clear image. To improve acoustic coupling, a water-soluble transmission gel was placed over the scan head.

The activity of the abdominal muscle is modulated by respiration, i.e. the thickness of the rectus abdominis increases during expiration $[31,39,40]$. Therefore, readings were taken at consistent points at the end of a released expiration (when the respiratory muscles were relaxed).

\section{Anthropometric measurements}

Materials for the anthropometric measurements include a calibrated weighing balance that was used to measure the weights of the subjects while the subject was standing erect with minimal clothing; a wall-mounted stadiometer with movable headpiece was used for the measurement of heights of subjects; and a plastic measuring tape $(60 \mathrm{inch} / 150 \mathrm{~cm}$, made in Shanghai, China) was used to assess abdominal circumference at the level of the umbilicus with the subject being in a relaxed state.

\section{Body mass index}

Body mass index (BMI) was calculated using the formula BMI = weight $(\mathrm{kg}) /(\text { height }(\mathrm{m}))^{2}$.

\section{Conicity index}

This was calculated using the formula designed by Teylor et al. [41]:

Conicity index $=$ waist circumference $/$ (0.109 $\times$ square root of weight/height). 


\section{Body surface area}

This was calculated by the formula below Body surface area $(\mathrm{BSA})=0.007184 \times \mathrm{W}^{0.426}$ $\times \mathrm{H}^{0.721}[42]$.

\section{Statistical analysis}

The statistical package for the social sciences (SPSS) software version 16.0 was used to analyse the generated data. Data was expressed as mean \pm standard deviation. Student's $t$-test was used to compare means, and Pearson's correlation was used to express relationships.

\section{Ethical approval}

In line with the Helsinki Declaration of 1989, ethical approval was obtained from the Research/Ethics committee of the Faculty of Basic Medical Sciences, Ebonyi State University, Abakaliki, Southeast Nigeria.

\section{Results}

Table 1 above shows that values of age, height, weight, BMI, BSA, WC, and CI are greater in males than in females, except for the conicity index, which is greater in females than in males (1134.68 in females vs. 1125.66 in males). The line graphs in Figures $1 \mathrm{~A}$ and $1 \mathrm{~B}$ show that the rectus abdominis thickness is greater in males than in females. Its thickness is also greater in the right side in males than it is in females.

The mean rectus abdominis thickness in young adult Nigerians is $14.52 \pm 2.72 \mathrm{~mm}$. The thickness of the RAM in both sexes shows that the right sides are significantly higher than the left sides $(p<0.05)$. Even in the general population, RAT was still thicker in males than in females $(p<0.05)$, as can be seen in the Table 2. These values corroborate the outcome of Figures 2 and 3.

Table 3 shows the difference between right rectus abdominis thickness (RRAT) and left rectus abdominis thickness (LRAT) in the general population, in males and in females. The difference in thickness between the right and left sides was not significant in the general population $(p=0.132)$. However, in males the RRAT was significantly greater than the LRAT $(p<$ $0.05)$. This significant level of difference was not seen in females $(p=0.272)$, who presented thicker LRAT than RRAT (Table 4).

Pearson's correlation coefficient test showed that there was significant correlation between the RAT and age, weight, height, BMI, BSA, and CI ( $p<0.5)$, as shown in the Table 5.

\section{Discussion}

Trunk musculoskeletal disorders, especially low back pain, have become common among different oc-

Table 1. Descriptive statistics for assessed anthropometric variables

\begin{tabular}{|lccc|}
\hline Anthropometric variables & General population (both sex) & Male & Female \\
Age $[$ years] & $23.62 \pm 2.49$ & $23.92 \pm 6.01$ & $23.05 \pm 2.16$ \\
Height $[\mathrm{m}]$ & $1.70 \pm 0.089$ & $1.74 \pm 0.072$ & $1.63 \pm 5.07$ \\
Weight $[\mathrm{kg}]$ & $66.58 \pm 10.78$ & $69.85 \pm 9.23$ & $60.50 \pm 11.03$ \\
BMI $\left[\mathrm{kg} / \mathrm{m}^{2}\right]$ & $22.94 \pm 2.83$ & $23.00 \pm 2.27$ & $22.84 \pm 3.72$ \\
BSA $\left[\mathrm{m}^{2}\right]$ & $1.77 \pm 0.18$ & $1.84 \pm 0.15$ & $1.65 \pm 0.17$ \\
WC $[\mathrm{cm}]$ & $76.74 \pm 6.90$ & $77.54 \pm 6.01$ & $75.25 \pm 8.26$ \\
Cl (conicity index) & $1128.81 \pm 56.68$ & $1125.66 \pm 58.81$ & $1134.68 \pm 53.40$ \\
\hline
\end{tabular}

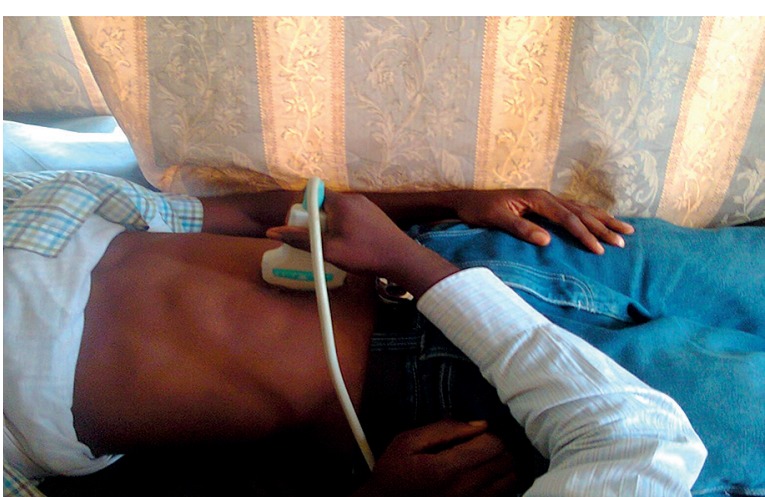

Figure 2. The machine and subject while measuring the thickness of the rectus abdominis

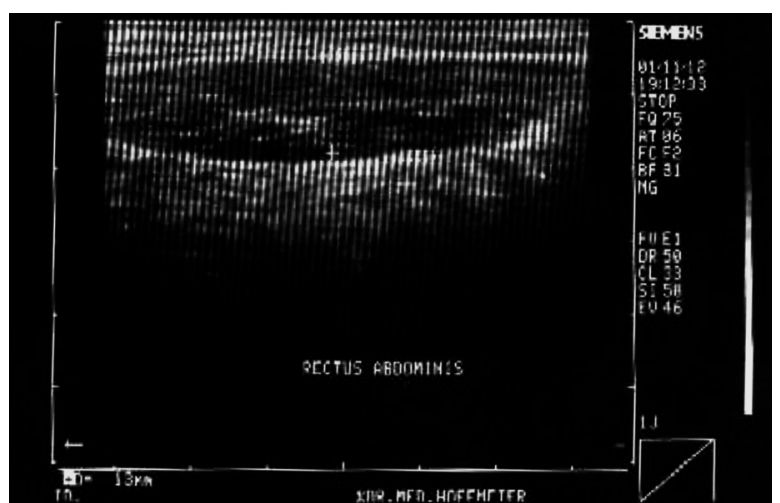

Figure 3. Sonogram of left rectus abdominis thickness in a young adult 
cupational groups. Trunk muscle biomechanics have been employed in the management of some of these disorders. The rectus abdominis muscle cannot be left out since it contributes greatly in stabilising the trunk.

The thickness of the Rectus abdominis muscle was assessed in a young adult population, and the results showed a mean thickness of $14.52 \pm 2.72 \mathrm{~mm}$ for the entire population and $15.24 \pm 2.58 \mathrm{~mm}$ and 13.19 $\pm 2.51 \mathrm{~mm}$ for male and female subjects, respectively. The RAMT values obtained in this study are higher than the results from previous studies. Rankin et al. [30] reported a mean thickness of $10.2 \pm 1.60 \mathrm{~mm}$ for the right RAM using ultrasound. Kim et al. [43] reported RAT at the level of the Xiphoid processas 9.58 $\pm 2.11 \mathrm{~mm}$ and $9.73 \pm 2.06 \mathrm{~mm}$ for the right and left sides, respectively. They also reported a thickness of $10.26 \pm 1.83 \mathrm{~mm}$ and $10.26 \pm 1.85 \mathrm{~mm}$ for right and left sides, respectively, at the level of the umbilicus in an adult female population. These observed disparities might be associated with environmental, racial, and ethnic factors. Another important factor may be due to the degree of physical activity of our subjects, having used relatively active adults at the peak of muscle development.

Generally, these values are of clinical importance in reconstructive surgeries involving the muscle. Phillips et al. [44] proposed that a proper thickness of the muscle when used in myocutaneous flap reconstructive surgeries is important for safe elevation and gives an insight into the functionality of the major supplying arterial pedicles. Consequently, reduced muscle thickness may be an indication of the setting in of muscle wasting following possible damage to the supplying pedicles with an associated reduction in its functional role in the trunk. On the other hand, a thin RAM will naturally leave the pedicles unprotected and prone to damage during extraction of myocutaneous flaps. Thus, information on the thickness of the

Table 2. RAT in young adults

\begin{tabular}{|lccc|}
\hline Status (gender) & RAT $[\mathrm{mm}]$ & RRAT $[\mathrm{mm}]$ & LRAT [mm] \\
Both sex (Listwise) & $14.52 \pm 2.72$ & $14.68 \pm 2.92$ & $14.37 \pm 2.74$ \\
Male & $15.24 \pm 2.58$ & $15.59 \pm 2.79$ & $14.90 \pm 2.55$ \\
Female & $13.19 \pm 2.51$ & $12.99 \pm 2.41$ & $13.39 \pm 2.85$ \\
Range & $9.1-20.5$ & $9.8-21.0$ & $8.2-20$ \\
\hline
\end{tabular}

Table 3. Comparison between sexes

\begin{tabular}{|c|c|c|c|c|c|c|c|}
\hline Gender & $N$ & Mean & Standard deviation & $T$ & $\mathrm{Df}$ & Value of $p$ & Decision \\
\hline $\begin{array}{l}\text { Rectus abdominis thickness right: } \\
\text { Male } \\
\text { Female }\end{array}$ & $\begin{array}{l}39 \\
21\end{array}$ & $\begin{array}{l}15.59 \\
12.99\end{array}$ & $\begin{array}{l}2.79 \\
2.41\end{array}$ & 3.61 & 58 & $0.001^{\star *}$ & Sig. \\
\hline $\begin{array}{l}\text { Rectus abdominis thickness left: } \\
\text { Male } \\
\text { Female }\end{array}$ & $\begin{array}{l}39 \\
21\end{array}$ & $\begin{array}{l}14.90 \\
13.39\end{array}$ & $\begin{array}{l}2.55 \\
2.85\end{array}$ & 2.09 & 58 & $0.041^{*}$ & Sig. \\
\hline $\begin{array}{l}\text { Rectus abdominis thickness general: } \\
\text { Male } \\
\text { Female }\end{array}$ & $\begin{array}{l}39 \\
21\end{array}$ & $\begin{array}{l}15.24 \\
13.19\end{array}$ & $\begin{array}{l}2.58 \\
2.51\end{array}$ & 2.97 & 58 & $0.004^{*}$ & Sig. \\
\hline
\end{tabular}

Tables 4. Paired samples statistics and test

\begin{tabular}{|lccccccc|}
\hline & $N$ & Mean & Standard deviation & $T$ & D $f$ & Value of $p$ & Decision \\
$\begin{array}{l}1^{\text {st }} \text { Pair } \\
\text { (general population): }\end{array}$ & & & & 1.53 & 59 & 0.132 & Not sig. \\
$\quad$ RRAT & 60 & 14.68 & 2.92 & & & & \\
$\quad$ LRAT & 60 & 14.37 & 2.73 & & & & Sig. \\
$2^{\text {nd }}$ Pair (male): & & & & 3.09 & 38 & 0.004 & Not sig. \\
$\quad$ RRAT & 39 & 15.59 & 2.79 & & & & \\
$\quad$ LRAT & 39 & 14.90 & 2.55 & & & & \\
3 $^{\text {rd }}$ Pair (female): & & & & -1.13 & 20 & & \\
$\quad$ RRAT & 21 & 12.99 & 2.41 & & & & \\
$\quad$ LRAT & 21 & 13.39 & 2.85 & & & & \\
\hline
\end{tabular}


Table 5. Correlation between RAT and anthropometric variables

\begin{tabular}{|c|c|c|c|c|c|c|c|c|c|c|}
\hline \multicolumn{2}{|c|}{ Assessed parameters } & Age & Weight & Height & BMI & BSA & $\begin{array}{c}\text { Waist } \\
\text { circumference }\end{array}$ & $\begin{array}{c}\text { Rectus } \\
\text { abdominal } \\
\text { thickness } \\
\text {-right }\end{array}$ & $\begin{array}{c}\text { Rectus } \\
\text { abdominal } \\
\text { thickness } \\
\text { - left }\end{array}$ & $\begin{array}{l}\text { Rectus } \\
\text { abdominal } \\
\text { thickness } \\
\text { average }\end{array}$ \\
\hline \multirow[t]{3}{*}{ Age } & Correlation & 1 & $0.501^{\star \star}$ & 0.139 & $0.545^{\star *}$ & $0.450^{* *}$ & $0.569^{\star *}$ & $0.456^{\star *}$ & $0.375^{\star *}$ & $0.434^{\star *}$ \\
\hline & Value of $p$ & & $<0.001$ & 0.291 & $<0.001$ & $<0.001$ & $<0.001$ & $<0.001$ & 0.003 & 0.001 \\
\hline & $N$ & 120 & 120 & 120 & 120 & 120 & 120 & 120 & 120 & 120 \\
\hline \multirow[t]{3}{*}{ Weight } & Correlation & $0.501^{\star *}$ & 1 & $0.684^{\star *}$ & $0.785^{\star *}$ & $0.989^{* *}$ & $0.814^{\star *}$ & $0.606^{* *}$ & $0.413^{* *}$ & $0.533^{* *}$ \\
\hline & Value of $p$ & $<0.001$ & & $<0.001$ & $<0.001$ & $<0.001$ & $<0.001$ & $<0.001$ & 0.001 & $<0.001$ \\
\hline & $N$ & 120 & 120 & 120 & 120 & 120 & 120 & 120 & 120 & 120 \\
\hline \multirow[t]{3}{*}{ Height } & Correlation & 0.139 & $0.684^{\star *}$ & 1 & 0.090 & $0.781^{\star *}$ & $0.391^{\star *}$ & $0.374^{\star *}$ & $0.280^{\star}$ & $0.342^{\star *}$ \\
\hline & Value of $p$ & 0.291 & $<0.001$ & & 0.492 & $<0.001$ & 0.002 & 0.003 & 0.030 & 0.008 \\
\hline & $N$ & 120 & 120 & 120 & 120 & 120 & 120 & 120 & 120 & 120 \\
\hline \multirow[t]{3}{*}{ BMI } & Correlation & $0.545^{\star \star}$ & $0.785^{\star \star}$ & 0.090 & 1 & $0.691^{\star \star}$ & $0.780^{\star \star}$ & $0.492^{\star \star}$ & $0.317^{\star}$ & $0.424^{\star *}$ \\
\hline & Value of $p$ & $<0.001$ & $<0.001$ & 0.492 & & $<0.001$ & $<0.001$ & $<0.001$ & 0.014 & 0.001 \\
\hline & $N$ & 120 & 120 & 120 & 120 & 120 & 120 & 120 & 120 & 120 \\
\hline \multirow[t]{3}{*}{ BSA } & Correlation & $0.450^{\star *}$ & $0.989^{* *}$ & $0.781^{\star \star}$ & $0.691^{\star *}$ & 1 & $0.773^{* *}$ & $0.593^{* *}$ & $0.409^{* *}$ & $0.524^{* *}$ \\
\hline & Value of $p$ & $<0.001$ & $<0.001$ & $<0.001$ & $<0.001$ & & $<0.001$ & $<0.001$ & 0.001 & $<0.001$ \\
\hline & $N$ & 120 & 120 & 120 & 120 & 120 & 120 & 120 & 120 & 120 \\
\hline \multirow{3}{*}{$\begin{array}{l}\text { Waist } \\
\text { circumference }\end{array}$} & Correlation & $0.569^{\star \star}$ & $0.814^{\star *}$ & $0.391^{\star *}$ & $0.780^{* *}$ & $0.773^{* *}$ & 1 & $0.580^{* *}$ & $0.446^{* *}$ & $0.536^{* *}$ \\
\hline & Value of $p$ & $<0.001$ & $<0.001$ & 0.002 & $<0.001$ & $<0.001$ & & $<0.001$ & $<0.001$ & $<0.001$ \\
\hline & $N$ & 120 & 120 & 120 & 120 & 120 & 120 & 120 & 120 & 120 \\
\hline \multirow{3}{*}{$\begin{array}{l}\text { Rectus } \\
\text { abdominal } \\
\text { thickness - } \\
\text { right }\end{array}$} & Correlation & $0.456^{\star *}$ & $0.606^{\star *}$ & $0.374^{* *}$ & $0.492^{* *}$ & $0.593^{* *}$ & $0.580^{* *}$ & 1 & $0.849^{* *}$ & $0.964^{\star *}$ \\
\hline & Value of $p$ & $<0.001$ & $<0.001$ & 0.003 & $<0.001$ & $<0.001$ & $<0.001$ & & $<0.001$ & $<0.001$ \\
\hline & $N$ & 120 & 120 & 120 & 120 & 120 & 120 & 120 & 120 & 120 \\
\hline \multirow{3}{*}{$\begin{array}{l}\text { Rectus } \\
\text { abdominal } \\
\text { thickness - } \\
\text { left }\end{array}$} & Correlation & $0.375^{\star \star}$ & $0.413^{\star \star}$ & $0.280^{\star}$ & $0.317^{\star}$ & $0.409^{\star *}$ & $0.446^{* *}$ & $0.849^{* *}$ & 1 & $0.959^{\star *}$ \\
\hline & Value of $p$ & 0.003 & 0.001 & 0.030 & 0.014 & 0.001 & $<0.001$ & $<0.001$ & & $<0.001$ \\
\hline & $N$ & 120 & 120 & 120 & 120 & 120 & 120 & 120 & 120 & 120 \\
\hline \multirow{3}{*}{$\begin{array}{l}\text { Rectus } \\
\text { abdominal } \\
\text { thickness - } \\
\text { average }\end{array}$} & Correlation & $0.434^{\star *}$ & $0.533^{\star *}$ & $0.342^{\star *}$ & $0.424^{\star *}$ & $0.524^{\star *}$ & $0.536^{\star \star}$ & $0.964^{\star *}$ & $0.959^{\star *}$ & 1 \\
\hline & Value of $p$ & 0.001 & $<0.001$ & 0.008 & 0.001 & $<0.001$ & $<0.001$ & $<0.001$ & $<0.001$ & \\
\hline & $N$ & 120 & 120 & 120 & 120 & 120 & 120 & 120 & 120 & 120 \\
\hline
\end{tabular}

${ }^{*}$ Correlation is significant at the 0.05 level (2-tailed). ${ }^{* *}$ Correlation is significant at the 0.01 level (2-tailed)

rectus abdominis muscle is clinically very important and can be helpful to the surgeon [45].

Other results from this study reveal that the RAMT in males was significantly thicker than those of females (Table 3; $p<0.05$ ). This is another manifestation of sexual dimorphism, which in this case is a consequence of male masculinity as a result of hormonal attributes and, possibly, a higher degree of physical activity. In line with our findings, Kanehisa et al. [29] earlier reported the effect of sex on the thickness of the abdominal muscles, which may indicate the degree of force generation and sexual dimorphism.
The results also showed that there was no significant difference between the RRAT and LRAT in the sample population and in female subjects. However, the RRAT was greater than the LRAT in the male subjects (Table 5). This significant difference in males could be a result of their postural tilt, which initiates a greater thickness inclined to the right side, following prolonged phases of high degrees of physical activity. It could be called masculinity-induced laterality of the muscle. The non-significant difference in the female subjects may be due to a possible lack of forceful activity associated with femininity. 
Table 6. Correlation between RAT and conicity index

\begin{tabular}{|lccc|}
\hline Parameter & \multicolumn{3}{c|}{ Conicity index } \\
\cline { 2 - 4 } & $\boldsymbol{N}$ & Pearson correlation & $P$ \\
Age & 60 & $0.269^{*}$ & 0.038 \\
Weight & 60 & 0.145 & 0.271 \\
Height & 60 & 0.073 & 0.577 \\
Waist circumference & 60 & $0.652^{* *}$ & $<0.001$ \\
$\begin{array}{l}\text { Rectus abdominal } \\
\text { thickness - right }\end{array}$ & 60 & 0.232 & 0.074 \\
$\begin{array}{l}\text { Rectus abdominal } \\
\text { thickness - left }\end{array}$ & 60 & $0.260^{*}$ & 0.045 \\
$\begin{array}{l}\text { Rectus abdominal } \\
\text { thickness - average }\end{array}$ & 60 & $0.255^{\star}$ & 0.049 \\
BMI & 60 & 0.131 & 0.318 \\
BSA & 60 & 0.136 & 0.300 \\
\hline
\end{tabular}

Correlation is significant at the 0.05 level (2-tailed)

Pearson's correlation coefficient showed a high degree of connectivity between the RAT and the assessed anthropometric variables: age, height, weight, BMI, BSA, WC, and CI (Tables 4 and 5). The correlation with age is in line with the findings of Kanehisa et al. [29], and this clearly infers the effect of age on the thickness of RAM. Its relationship with weight could be explained in its trunk stabilising role associated with the weight of the trunk. Its extent in the anterior abdominal wall obviously contributed to its significant relationship with the height of the subjects, and because of these relationships with weight and height, it is significantly associated with the BMI and BSA. Its relationship with WC and CI may indicate its position in the anthropometric assessment of the trunk, bearing in mind the connection between WC, CI, and intra-abdominal adipose tissue thickness, subcutaneous adipose tissue thickness as reported by Njoku [46], and in the evaluation of fatness as reported by Rostami et al. [36].

The myoanthropometric relationships observed in this study are the first set of relationships of the rectus abdominis muscle reported for a Sub-Saharan African population. Hence, its novelty in this environment will initiate investigations of the clinical and biomechanical aspects of the muscle with regards to its role in lifting sports among Africans. Since the value of RAT in this study is seen to be higher than previously reported values, it is necessary to explore possible biomechanical and sports-related advantages that could be associated with these results in our environment. The reported myoanthropometric relationships could also be used in the assessment of trunk mass and the muscle's possible role in the mechanical aspects of respiration.

\section{Conclusions}

Males have a significantly higher RAMT than females. The values of RAMT seen in this study are higher than those of previous studies. The RAMT correlates positively with age, weight, height, BMI, BSA, $\mathrm{WC}$, and CI. These myoanthropometric relationships will serve as a guidepost in the clinical and biomechanical assessment of the muscle and its role in the assessment of trunk mass and stability in an African population.

\section{References}

1. Fukunaga T, Kantakami Y, Kuno S, et al. Muscle architecture and function in humans. J Biomech 1997; 30: 457-63.

2. Aagaard P, Andersen JL, Dyhre-Poulsen P, et al. A mechanism for increased contractile strength of human pinnate muscle in response to strength training: changes in muscle architecture. J Physiol 2001; 534: 613-23.

3. Lieber RL, Friden J. Clinical significance of skeletal muscle architecture. Clin Orthop Relat Res 2001; 383: 140-51.

4. Fukunaga T, Ichinose $Y$, Ito $M$, et al. Determination of fascicle length and pennation in a contracting human muscle in vivo. J Appl Physiol 1997; 82: 354-8.

5. Maganaris CN, Baltzopoulos V, Sargeant AJ. In vivo measurement of triceps surae complex architecture in man: implication of muscle function. J Physiol 1998; 2: 603-14.

6. Rutherford OM, Jones DA. Measurement of fibre pennation using ultrasound in the human quadriceps in vivo. Eur J Appl Physiol 1992; 65: 433-7.

7. Egwu O, Njoku C, Ukoha U, et al. Calf muscle (triceps surae complex) thickness in an adult Nigerian population: an imaging based normographic study. Maced J Med Sci 2013; 6: 146-52.

8. Heckmatt JZ, Pier N. Dubowitz V. Assessment of quadriceps femoris muscle atrophy and hypertrophy in neuromuscular disease in children. J Clin Ultrasound 1988; 16: 177-81.

9. Miyatani M, Kanehisa H, Ito M, et al. The accuracy of volume estimates using ultrasound muscle thickness measurements in different muscle groups. Euro J Appl Physiology 2004; 91: 264-72.

10. Lee CD, Song Y, Peltier AC, et al. Muscle ultrasound quantifies the rate of reduction of muscle thickness in amyotrophic lateral sclerosis. Muscle Nerve 2010; 42: 814-9.

11. Moreau NG, Simpson KN, Teefey SA, et al. Muscle architecture predicts maximum strength and is related to activity levels in cerebral palsy. Phys Ther 2010; 90: 1619-30.

12. Teyhen DS, Miltenberger CE, Deiters HM, et al. The use of ultrasound imaging of the abdominal drawing-in maneuver in subjects with low back pain. J Orthop Sports Phys Ther 2005; 35: 346-55.

13. Hicks GE, Fritz JM, Delitto A, et al. Preliminary development of a clinical prediction rule for determining which patients with low back pain will respond to a stabilization exercise program. Arch Phys Med Rehabil 2005; 86: 1753-62.

14. Saal JA. Dynamic muscular stabilization in the nonoperative treatment of lumbar pain syndromes. Orthop Rev 1990; 19: 691-700. 
15. O’Sullivan PB, Twomey LT, Allison GT. Evaluation of specific stabilizing exercise in the treatment of chronic low back pain with radiologic diagnosis of spondylolysis of spondylolisthesis. Spine 1997; 22: 2959-67.

16. Young WA, Wright JK. Scrotal reconstruction with a rectus abdominis muscle flap. Br J Plastic Surg 1988; 41: 190-3.

17. Robbins TH. Rectus abdominis myocutaneous flap for breast reconstruction. Aust N Z J Surg 1979; 49: 527-30.

18. Arnez ZM, Smith RW, Eder E, et al. Breast reconstruction by the free lower transverse rectus abdominis musculocutaneous flap. Br J Plast Surg 1988; 41: 500-5.

19. Fernando B, Muszynski C, Mustoe T. Closure of a sternal defect with the rectus abdominis muscle after sacrifice of both internal mammary arteries. Ann Plastic Surg 1988; 21: 468-71.

20. Urken ML, Turk JB, Weinberg H, et al. The rectus abdominis free flap in head and neck reconstruction. Arch Otolaryngol Head Neck Surg 1991; 117: 1031.

21. Carey JN, Sheckter CC, Watt AJ, et al. Intra-abdominal pedicled rectus abdominis muscle flap for treatment of high-output enterocutaneous fistulae: case reports and review of literature. J Plast Reconstr Aesthet Surg 2013; 66: $1145-8$.

22. Jinming Z, Xiaoxuan C, Jieren $P$, et al. The rectus abdominis musculoperitoneal (RAMP) flap for the reconstruction of complicated pharyngoesophageal defects. Br J Plastic Surg 2005; 58: 608-13.

23. Press BHJ, Chiu DT, Cunningham BL. The rectus abdominis muscle in difficult problems of hand soft tissue reconstruction. Br J Plastic Surg 1990; 43: 419-25.

24. Bruce RG, El-Galley RE, Galloway N. Use of rectus abdominis muscle flap for the treatment of complex and refractory urethrovaginal fistulas. J Urology 2000; 163: 1212-5.

25. Atan A, Tuncel A, Aslan Y. Treatment of refractory urethrovaginal fistula using rectus abdominis muscle flap in a six-year-old girl. Urology 2007; 69: 384-11.

26. Galli A, Raposio E, Santi P. Reconstruction of full-thickness defects of the thoracic wall by myocutaneous flap transfer: latissimus dorsi compared with transverse rectus abdominis. Scand J Plast Reconstr Surg Hand Surg 1995; 29: 39-43.

27. Reath DB, Taylor JW. The segmental rectus abdominis free flap for ankle and foot reconstruction. Plastic Reconstruct Surg 1991; 88: 824-8.

28. Ikezoe T, Mori N, Nakamura M, et al. Effects of age and inactivity due to prolonged bed rest on atrophy of trunk muscles. Eur J Appl Physiol 2012; 112: 43-8.

29. Kanehisa H, Miyatani M, Azuma K, et al. Influences of age and sex on abdominal muscle and subcutaneous fat thickness. Eur J Appl Phyiol 2004; 91: 534-7.

30. Rankin G, Stokes M, Newham DJ. Abdominal muscle size and symmetry in normal subjects. Muscle Nerve 2006; 34 . 320-6.

31. Ainscough-Potts AM, Morrissey MC, Critchley D. The reponse of the transverse abdominis and internal obique muscles to different postures. Man Ther 2006; 11: 54-60.

32. Ikezoe T, Mori N, Nakamura M, et al. Age-related muscle atrophy in the lower extremities and daily physical activity in elderly women. Arch Gerontol Geriatr 2011; 53: e153-7.

33. Balius R, Pedret C, Galilea P, et al. Ultrasound assessment of asymmetric hypertrophy of rectus abdominis muscle and prevalence of associated injury in professional tennis players. Skeletal Radiol 2012; 41: 1575-81.

34. Ononogbu IC. Food biochemistry and Nutrition Gico Tech. Nigeria Ltd. Publishers Nsukka Nigeria 1997; 20-70.

35. Coldron Y, Stokes MJ, Newham DJ, et al. Postpartum characteristics of rectus abdominis on ultrasound imaging. Manual Therapy 2008; 13: 112-21.

36. Rostami M, Yekta AHA, Noormohammadpour P, et al. Relations between lateral abdominal muscles thickness, body mass index, waist circumference and skin fold thickness. Acta Med Iran 2013; 51: 101-6.

37. Campbell IT, Watt T, Withers D, et al. Muscle thickness, measured with ultrasound, may be an indicator of lean tissue wasting in multiple organ failure in the presence of edema. Am J Clin Nutr 1995; 62: 533-9.

38. Narici MV. Human skeletal muscle architecture studied in vivo by non-invasive imaging techniques: functional significance and applications. J Electromyogr Kinesiol 1999; 9: 97-103.

39. De Troyer A, Estenne M, Ninane V, et al. Transversus abdominis muscle function in humans. J Appl Physiol 1990; 68: 1010-6.

40. Misuri G, Colagrande S, Gorini M, et al. In vivo ultrasound assessment of respiratory function of abdominal muscles in normal subjects. Eur Respi J 1997; 10: 2861-7.

41. Taylor RW, Jones IE, Williams SM, Goulding A. Evaluation of waist circumference, waist-to-hip ratio, and the conicity index as screening tools for high trunk fat mass, as measured by dual-energy X-ray absorptiometry, in children aged 3-19 y. Am J Clin Nutr 2000; 72: 490-5.

42. du Dubois D, du Dubois EF. A formula to estimate the approximate surface area if height and weight be know. Nutrition 1989; 5: 303-11.

43. Kim J, Lim H, Lee SI, et al. Thickness of rectus abdominis muscle and abdominal subcutaneous fat tissue in adult women: correlation with age, pregnancy, laparotomy, and body mass index. Arch Plastic Surgery 2012; 39: 528-33.

44. Phillips TJ, Stella DL, Rozen WM. Abdominis wall CT angiography a detailed account of a newly established preoperative imaging technique. Radiology 2008; 249: 32-44.

45. Suh IS, Bang RS, Park KN. Analysis of subcutaneous tissue thickness of the flap donor sites by ultrasography. J Korean Soc Plast Reconstr Surg 1992; 19: 534-7.

46. Njoku CO. Songraphic assessment of android adipose tissue thickness in Ebonyi population: A correlation with anthropometric variables. M.Sc. Dissertation, Ebonyi State University, Abakaliki, Nigeria 2010.

\section{Address for correspondence:}

Ogugua Augustine Egwu

Federal University, Ndufu-Alike Ikwo

P.M.B 1010, 234 Abakaliki, Nigeria

Phone: +2348034518414

E-mail: egwuoc@gmail.com 